\title{
BROOD SIZE AND FOOD HABITS OF GREAT HORNED OWLS NEAR CALGARY, ALBERTA
}

\author{
HAROLD W. PINEL, 1017 - 19 Avenue N.W., Calgary, Alberta
}

From 1975 through 1977, I banded 125 flightless young Great Horned Owls in the Calgary area. The 60 nests were in agricultural areas up to 100 road miles from Calgary. I am indebted to Dan Sikorski and John Riddell for their skilled assistance in spotting the nests and banding the young owls, and to Richard Fyfe and Harry Armbruster of the Canadian Wildlife Service for their aid in obtaining a sub-permit and the necessary bands for me.
Owls were banded by the author a spare time permitted. During the thre years, the optimum time for bandin owls in the Calgary area was the las week in April and the first week i May. This is approximately two $t$ three weeks earlier than C. S. Housto reported for Saskatchewan. ${ }^{2}$ Mos nests were visited only once with 3 owls being banded in April and 95 i May. The earliest banding date w? April 13, 1977, while the latest wa

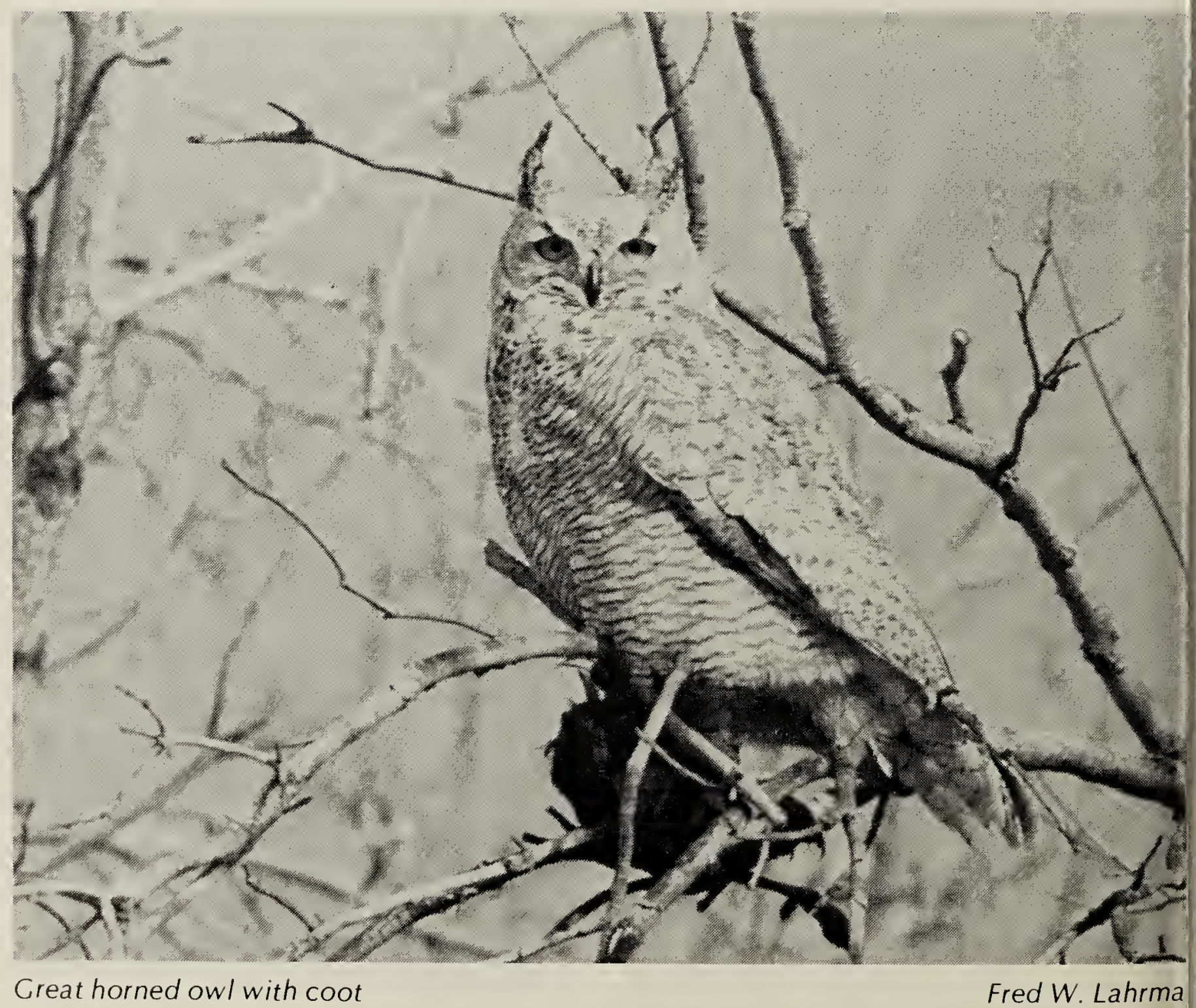




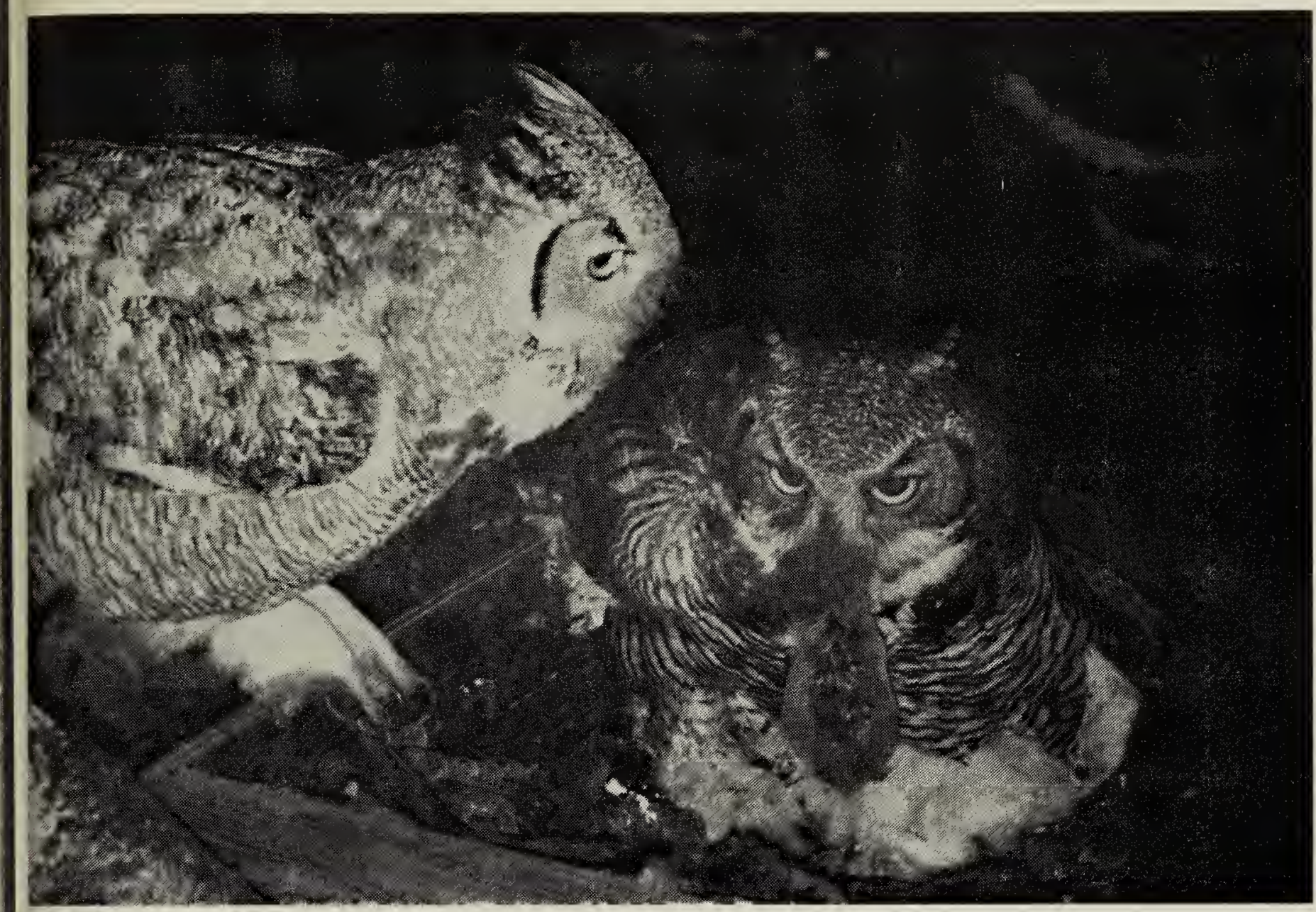

Great horned owl feeding his mate

Lorne Scott

May 19, 1975. Besides banding the young owls, the author recorded food items in the nest. A number of nests contained no prey during my visit, while very large nests did not allow the climber to see the contents. Pellets were not examined.

Nest success in 1975 was better than in 1976 or 1977 with an average of 2.5 young per nest and with $50 \%$ of the nests containing three of four young (Table 1). Although I have no figures for the density of prey species (hares, pocket gophers, water birds and mice), water birds were noticeably more plentiful during 1975 than in subsequent years. This was verified by habitat conditions and the proportions of aquatic species of birds visible in nests (Table 2). Some sloughs present in the spring of 1975 dried up by 1976 and even more disappeared by the 1977 nesting season.

The number of prey species found in
Great Horned Owl nests was 60; 29 of the food items being birds and 31 mammals. In 1975, 100\% of the prey items were birds as compared to $57 \%$ in 1976 and $34 \%$ in 1977.

The most abundant prey items found in Great Horned Owl nests were Varying Hare (Lepus americanus), Pintail, Richardson's Ground Squirrel (Spermophilus richardsonii) and Pocket Gopher (Thomonys talpoides). The Varying Hare was also found the most important prey in Manitoba by Bird, and in central Alberta by Mclnvaille and Keith. ${ }^{3}$ It is intersting that Richardson's Ground Squirrel, a diurnal mammal, composed over $25 \%$ of the mammals found in the owl nests. Another feature was the low numbers of mice and voles found. It may be that because of their small size, there was less chance of finding uneaten portions in nests or that the adults were consuming them and 


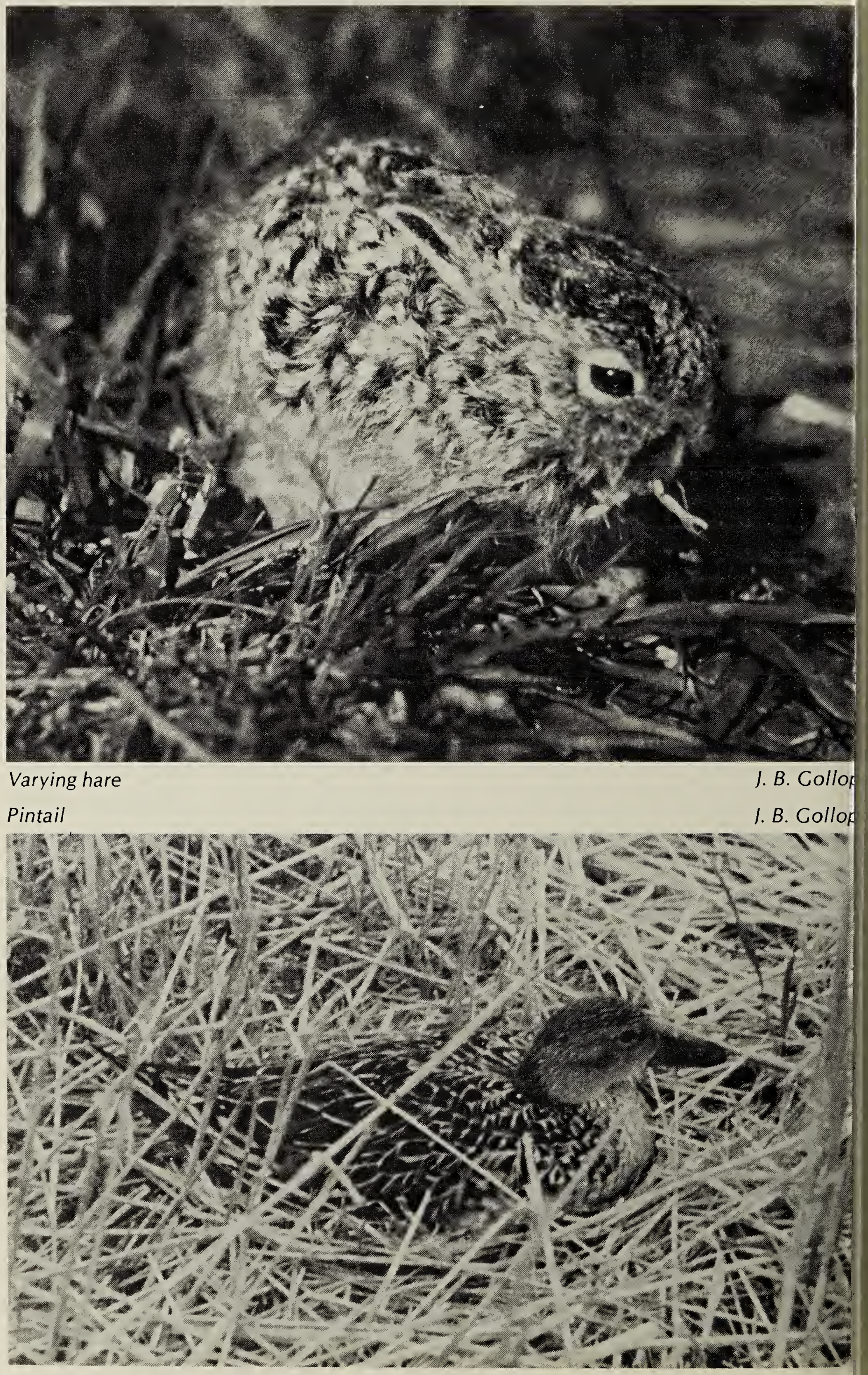




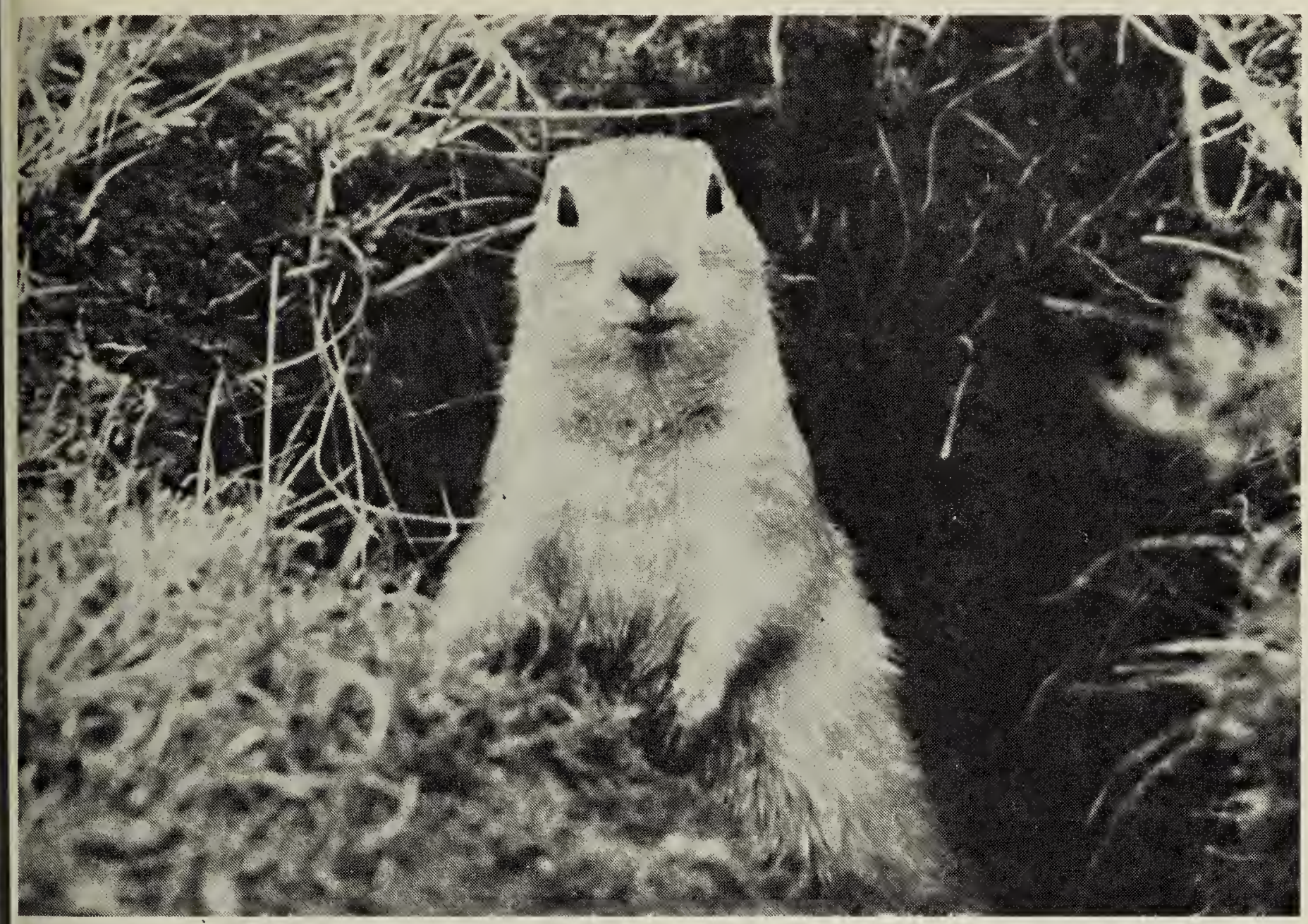

Richardson's ground squirrel

Frank Switzer

Pocket gophers left for food in ow/ nest

Lorne Scott

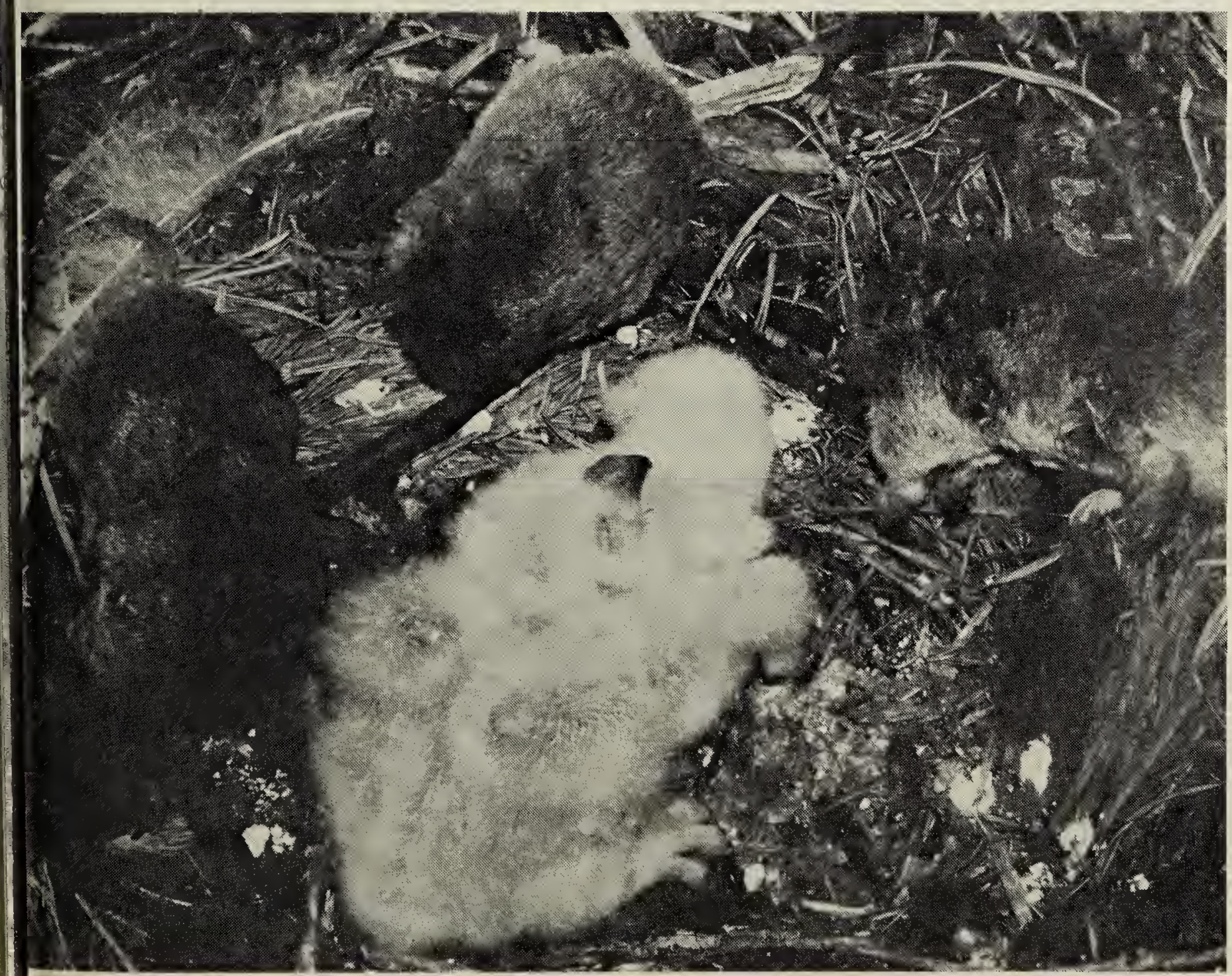




\begin{tabular}{lllllllll}
\multicolumn{1}{c}{ Number Nests With: } & Total & Total & Average & $\begin{array}{l}\text { Total } \\
\text { No. }\end{array}$ & $\begin{array}{l}\text { Young } \\
\text { Banded }\end{array}$ \\
Year & 4 yg. & 3 yg. & 2 yg. & 1 yg. & Nests & Young & Young & Band \\
1975 & 2 & 3 & 3 & 2 & 10 & 25 & 2.5 & 25 \\
1976 & 0 & 5 & 12 & 4 & 21 & 43 & 2.0 & 43 \\
1977 & 1 & 8 & 11 & 9 & 29 & 59 & 2.0 & 57 \\
TOTALS & 3 & 16 & 26 & 15 & 60 & 127 & 2.1 & 125
\end{tabular}

Table 2. PREY ITEMS RECORDED IN GREAT HORNED OWL NESTS, 1975-1977

Prey Species

Number of Individuals

197519761977

\begin{tabular}{|c|c|c|}
\hline BIRDS & & \\
\hline Mallard & & 2 \\
\hline Mallard egg & & 1 \\
\hline Pintail & 1 & 8 \\
\hline Pintail egg & 1 & \\
\hline Sharp-shinned & & \\
\hline Hawk & & 1 \\
\hline Ring-necked & & \\
\hline Pheasant & 1 & \\
\hline Gray Partridge & & \\
\hline American Coot & & 1 \\
\hline Rock Dove & & \\
\hline Short-eared Owl & & 1 \\
\hline Horned Lark & & 1 \\
\hline Common Crow & & 1 \\
\hline Common Starling & & \\
\hline SUB-TOTAL & 3 & 16 \\
\hline MAMMALS & & \\
\hline White-tailed & & \\
\hline Prairie Hare & & 3 \\
\hline Varying Hare & & 3 \\
\hline Richardson's & & \\
\hline Ground Squirrel & & 4 \\
\hline Pocket Gopher & & 1 \\
\hline Deer Mouse & & \\
\hline Meadow Vole & & 1 \\
\hline SUB-TOTAL & 0 & 12 \\
\hline TOTAL & 3 & 28 \\
\hline
\end{tabular}

bringing larger prey to the young owls. Orians and Kuhlman found a similar situation in Wisconsin. ${ }^{4}$ In pellet analysis, they found Peromyscus and Micortus well represented, but in the nest inspections, only one animal o each genus was found.

Odd items of prey included a Pinta egg in one nest in 1975 and a Mallar egg in another in 1976. In both cases, female of the species was found in th nest with the egg, suggesting that th ducks were not completely dead aft being carried to the nest. ${ }^{*}$ Items c prey such as Sharp-shinned Hawl Short-eared Owl, Rock Dove, Crov Starling and Horned Lark illustrate th Great Horned Owls' capabilities an flexibility, and, also, the shortage c preferred prey items.

*EDITOR'S NOTE: In a paper entitled "Eg of Other Species in Great Horned Or Nests" (Auk 92:377-378. 1975), C. S. Housto and D. W. A. Whitfield give details of nir such cases. They speculated that these eg were within the bodies of laying hens whe brought to the nest and were either expelle there by live birds or left after the owls he eaten the birds' flesh.

'BIRD, R. D. 1929. The Great Horned Owl Manitoba. Canadian Field-Nat. 43(4):7 83.

${ }^{2}$ HOUSTON, C. S. 1971. Brood size of $t$ Great Horned Owl in Saskatchewa Bird Banding 42(2):103-105.

${ }^{3}$ MCINVAILLE, W. B. and L. B. KEITH. 197 Predator-prey relations and breedi biology of the Great Horned Owl ar Red-tailed Hawk in central Albert Canadian Field-Nat. 88(1):1-20.

${ }^{4}$ ORIANS, G. and F. KUHLMAN. 1956. Re tailed Hawk and Horned OI populations in Winsconsin. Cond 58(5):371-385. 